\title{
Trade-offs between ecosystem services and alternative pathways toward sustainability in a tropical dry forest region
}

\author{
$\underline{\text { Francisco Mora }}^{1}, \underline{\text { Patricia Balvanera }}^{1}$, Eduardo García-Frapolli $^{1}, \underline{\text { Alicia Castillo }}^{1}, \underline{\text { Jenny M. Trilleras }}^{1,2}, \underline{\text { Daniel Cohen-Salgado }}^{1}$ \\ and Oscar Salmerón ${ }^{1}$
}

\begin{abstract}
The design of strategies aimed at sustainable resource management requires an understanding of the trade-offs between the ecosystem services at stake, to determine appropriate ways in which to navigate them. We assess trade-offs between forage production for cattle ranching and the maintenance of carbon stocks or tree diversity in a Mexican tropical dry forest. Trade-offs between pairs of services were assessed by identifying their efficiency frontiers at both site and landscape scales. We also estimated service outcomes under current and hypothetical land-management conditions. We found stark trade-offs between fodder and carbon stocks and between fodder and tree species richness at the site scale. At the landscape scale, the efficiency frontier was concave, with a much less pronounced trade-off in the fodder-species richness case. Our estimates of current service supply levels showed a reduction of $18-21 \%$ for $\mathrm{C}$ stock and $41-43 \%$ for fodder biomass, relative to the maximum feasible values along the efficiency frontier. Choice of the optimum management strategy to reduce such inefficiency depended on deforestation level: secondary forest regeneration was most suitable when deforestation is low, whereas increased fodder productivity in the pastures is best when deforestation is high. Pasture enrichment with forage trees and secondary forest growth are potential management alternatives for achieving sustainability given the range of enabling ecological factors and to balance ecological and social sustainability given the requirements and preferences of local stakeholders. Given that analogous trade-offs are found across the tropics, this work contributes to reconciling tropical forest maintenance and its use for sustainable rural livelihoods.
\end{abstract}

Key Words: biodiversity; carbon; cattle; conservationists; fodder; forest management; peasants; production possibility frontier

\section{INTRODUCTION}

Humans often enhance the delivery of provisioning services at the cost of reductions in regulating or supporting ones (Rodríguez et al. 2006, Raudsepp-Hearne et al. 2010). In tropical dry forest (TDF) regions, landowners often clear their forest and establish pastures for cattle ranching (Burgos and Maass 2004, SánchezAzofeifa and Portillo-Quintero 2011) because livestock constitutes a private commodity, which is tradable in established markets from which short-term net returns can be obtained, but also because livestock functions much like a "savings account" that can be used to obtain cash for financial emergencies (Gerritsen et al. 2007, Casas et al. 2008). However, forest clearance causes greenhouse gases emissions (Achard et al. 2014), imbalances in local and regional climate regulation (AndersonTeixeira et al. 2012), loss of biodiversity and related services (de Albuquerque et al. 2005, Soto 2009), and reduced soil productivity (Maass et al. 1988, Trilleras et al. 2015). All of these effects are related to the loss of regulating or supporting services, most of which are public goods (McKean 2000) for which landowners are not economically compensated or which have longer return times.

Management of transformed landscapes for continued service supply without compromising regulatory or support services, including biodiversity, remains a challenge (Polasky et al. 2008, Tallis et al. 2008, Brown and Mumby 2014, Gilroy et al. 2014). Identification of trade-offs and synergies among services is of central importance to this aim (Raudsepp-Hearne et al. 2010, Ruijs et al. 2013). For example, maintenance of carbon stocks and biodiversity, two of the most important services provided by tropical dry forest landscapes (Balvanera et al. 2011, PortilloQuintero et al. 2015), depends on the interplay between trade-offs at the local scale driving deforestation and socioeconomic factors at landscape or regional scales that act to modulate forest clearance. At the local scale, the growth of exotic grasses on which cattle feed is not compatible with the reduced sunlight available in the forest understory (Beale 1973, Sircely and Naeem 2012). Thus, forests are cleared to increase grass productivity. However, given the low revenues from cattle ranching, limitations of labor availability, and the reliance on multiple economic activities by rural families (Lambin et al. 2003), clearing does not dominate the entire landscape. Moreover, small landowners value the conservation of some portions of their forest for alternative sources of fodder and forest products (Harvey and Haber 1999, Barrance et al. 2003) and for the contribution of the forest to the maintenance of life (Castillo et al. 2005). Identifying and quantifying such trade-offs is therefore crucial to advance the design of management strategies aimed at balancing local private and regional or global public benefits.

A conceptual framework within which to assess trade-offs between ecosystem services has been recently developed by Cavender-Bares et al. (2015). The trade-off between two services can be described using an efficiency frontier, which is the combination of maximum feasible values that can be obtained for the two services under the current biophysical and management conditions. The current condition of the system in relation to this optimal condition, i.e., its current efficiency, can be assessed, allowing identification of pathways associated to particular management practices and the ecological and social factors that enable or prevent the system from moving toward or along this frontier (King et al. 2015).

We applied the framework in this study to assess trade-offs among services in a tropical dry forest region in western Mexico. We used

${ }^{1}$ Instituto de Investigaciones en Ecosistemas y Sustentabilidad, Universidad Nacional Autónoma de México, ${ }^{2}$ Universidad de Ciencias Aplicadas y Ambientales 
data from a long-term social-ecological research site (Castillo et al. 2005, Maass et al. 2005, Martínez-Ramos et al. 2012) and a simulation approach to assess trade-offs among cattle production, carbon stock maintenance, and biodiversity conservation at both site and landscape scales. We asked the following specific questions: (1) what is the nature of the trade-offs between cattle production, carbon stock maintenance and biodiversity conservation at site scale? (2) how do these trade-offs change when comparing site and landscape scales? and (3) how efficient is the current landscape configuration for delivering those services? Finally, we discuss alternative management conditions and associated pathways with higher potential for sustainability based on discussion of the ecological and social factors that enable or inhibit each pathway.

\section{METHODS}

\section{Study region}

This study is focused on the area surrounding the ChamelaCuixmala Biosphere Reserve (CCBR) on the Mexican Pacific

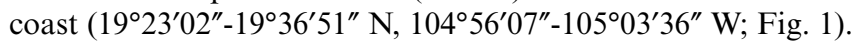
Mean annual temperature in the region is $24.6^{\circ} \mathrm{C}$ and mean annual precipitation is $788 \mathrm{~mm}$. Precipitation is strongly concentrated between November and May (García-Oliva et al. 2002). The predominant landforms are hills and flatlands, accounting for $\sim 89 \%$ and $11 \%$ of the landscape, respectively (Castillo et al. 2005). The hills have moderately to extremely steep slopes and nutrient-poor soils (Cotler et al. 2002) on which tropical dry forest occurs (Durán et al. 2002). The flatlands include floodplains and valleys along the main rivers and seasonal streams, with more profound, nutrient-rich soils on which tropical semievergreen forests occur (Durán et al. 2002).

Fig. 1. Study site location. Ejidos are areas with semicommunal land ownership that surround the Chamela-Cuixmala Biosphere Reserve (CCBR).

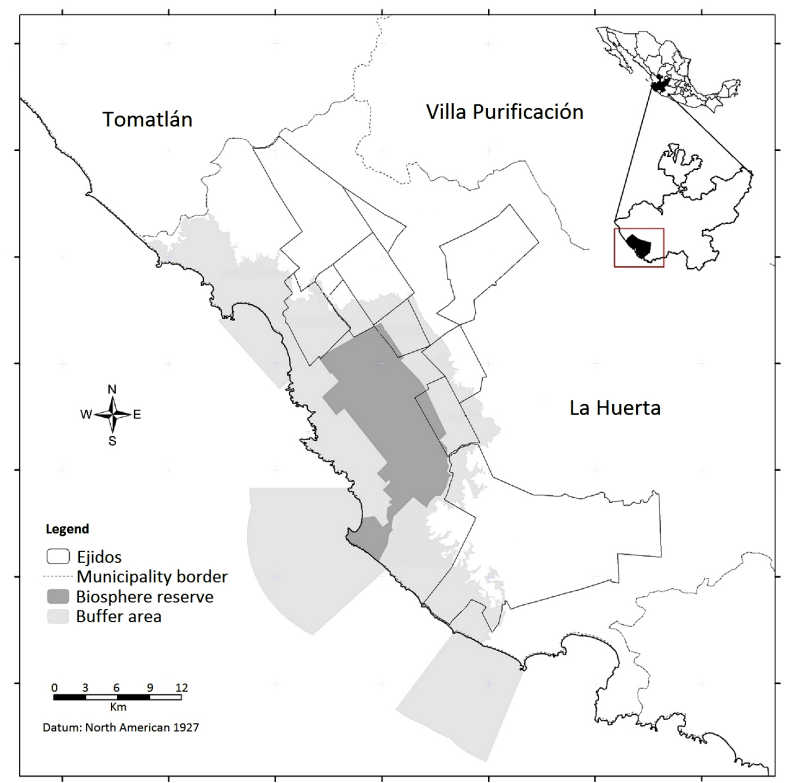

Although the territory of the CCBR has been dedicated to strict conservation and scientific research purposes since 1993, adjacent areas have been transformed to different degrees by agricultural activities over the last 50 years (Maass et al. 2005). Peasants have slashed and burned parts of their land to grow crops on the flatlands and to establish pastures for cattle ranching on the hills (Burgos and Maass 2004, Cohen Salgado 2014). However, pastures are sometimes abandoned and then covered by secondary forest, which can be used along with remnant oldgrowth forests for timber, stakes and firewood extraction, as well as cattle ranching (Rendón-Carmona et al. 2009, Cohen Salgado 2014).

\section{Ecosystem services assessed}

We assembled a dataset of 55 sites, located within and around the CCBR, for which fodder availability (used here as a proxy for cattle production), above-ground carbon stocks, and tree species richness (used as a proxy for biodiversity) were estimated (Martínez-Harms 2010, Quijas 2012, Mora et al. 2015, Trilleras et al. 2015). The sites all featured one of three different land-cover types: active pastures (28), secondary forests (14), and old-growth forests (13), all present under biophysical conditions in which TDF had historically existed. The management regime of pastures ranged from those established only 1-3 years prior to the study with no posterior maintenance, to those established 30 years previously that had been subjected to repeated slash and burn events (Trilleras et al. 2015). The secondary forests ranged from sites with short tree canopies $(\approx 2 \mathrm{~m})$, to forests with a structure and composition similar to that of old-growth forests. The oldgrowth forests included sites subjected to extraction of forest products or cattle browsing and sites under regimes of strict conservation within the reserve (Martínez-Harms 2010, Quijas 2012, Mora et al. 2015).

Fodder availability was approximated as the biomass of all the plants $<1 \mathrm{~cm}$ in diameter at breast height (DBH) within $1 \mathrm{~m}^{2}$ plots, averaged from 2, 3, and 5 samples per site (in 19, 12, and 24 sites, respectively, depending on the data source). In pastures, this biomass is composed mainly of exotic grasses, whereas in oldgrowth and secondary forests, it is composed by a large diversity of native herbs, small shrubs, and tree seedlings typical of the forest understory (Maza-Villalobos et al. 2011; M. R. OcampoDominguez 2012, unpublished manuscript). This definition includes the plant layer that is most actively consumed by cattle; because of the lack of data, it does not include the leaves and fruits (especially pods) consumed by cattle above $1 \mathrm{~m}$ from ground level or when fallen. Samples were oven-dried to determine dry mass. We reported the average biomass per site.

Above-ground carbon stock (hereafter $\mathrm{C}$ stock) was estimated from tree (all of the live shrubs and trees $\geq 1 \mathrm{~cm} \mathrm{DBH}$ ) and fodder components. For the tree component, tree censuses were taken using two plot sizes: $400 \mathrm{~m}^{2}$ square plots (19 sites), and $1000 \mathrm{~m}^{2}$ rectangular plots (36 sites). For the first plot size, individuals of $>1.0,>2.5$, and $>0 \mathrm{~cm}$. The diameter at breast height were measured within nested plots of 25,100 , and $400 \mathrm{~m}^{2}$, respectively. For the second plot size, individuals $>1.0,>2.5$, and $>10.0 \mathrm{~cm}$ DBH were measured within nested rectangular plots of 500,1000, and $1800 \mathrm{~m}^{2}$. Above-ground living tree biomass was estimated using an allometric equation that relates tree biomass to DBH (Martínez-Yrízar et al. 1992). Fodder biomass was estimated as 
described above. Biomass of the tree and fodder components was transformed to $\mathrm{C}$ stocks using corresponding carbon concentration values (Jaramillo et al. 2003).

Tree species richness was estimated using the same tree censuses. To render our estimations of the number of species comparable among sites, we used a standardization approach known as rarefaction (Gotelli and Colwell 2001), which accounts for differences in tree density and sampling protocols among sites. For sites with more than 30 individuals $>2.5 \mathrm{~cm} \mathrm{DBH}$ in the census (27 sites), rarefaction was performed using vegan library for R (Oksanen et al. 2011). For sites with less than 30 individuals (28 sites, all of them current pastures with less than 10 individuals), the observed tree species richness was used.

\section{Trade-offs assessment}

We defined efficiency frontiers for both site and landscape scales to assess the trade-off between fodder availability and aboveground carbon stocks or tree species richness (Cavender-Bares et al. 2015).

\section{Site-scale trade-offs}

At site scale, we defined the carbon stock-fodder and tree diversity-fodder efficiency frontiers as the upper limits of their bivariate data clusters using the data from the 55 sampled sites. We used a simple, heuristic approach, which consisted of fitting a four-parameter logistic function to the data cluster such that no data point lies above the curve formed by the function:

$$
\operatorname{Serv}_{\text {front }}=\operatorname{Ser} v_{\min }+\frac{\operatorname{Serv}_{\text {max }}}{\left(1+e^{((a-\text { Fodder }) / b)}\right)}
$$

This function defines the efficiency frontier as presenting a sigmoidal decay form. Serv front is the value of C stock or species richness on the frontier as a function of Fodder. The sum of Serv ${ }_{\text {min }}$ and Serv $v_{\max }$ provides an estimate of the asymptotic initial value of Serv $v_{\text {front }}$ as fodder approaches its minimum. Parameter $b$ defines the rate of decay, with parameter $a$ defining the fodder values at which the inflexion occurs. Finally, Serv ${ }_{\min }$ defines the asymptotic minimum value of $\operatorname{Serv}_{\text {front }}$ as fodder increases toward its maximum.

Selection of the most adequate parameter estimates was performed through repeated fitting following a numerical optimization procedure. We first fitted the function for $10^{4}$ parameter combinations (10 initial values for each parameter) using the "nls2" package with the "brute-force" approach in R (R Development Core Team 2015). We then selected the fits for which the residuals were all negative, i.e., all the points lie below the line. Finally, we selected the fits for which the sum of residuals was above the $99^{\text {th }}$ percentile, i.e., those minimizing the overall distance between the points and the line. The resulting range of values for the parameters in those fits was used to define subsequent initial values for the next fitting round. The process was repeated until the difference between the sums of residuals from subsequent models was less than $1 \%$.

Two different fits were run for each data cluster. The first fit included all data points (the complete data fit), whereas the second excluded the most extreme $5 \%$ of $\mathrm{C}$ stock and species richness values, to eliminate the effect of extreme values (the $95 \%$ data fit). To identify such extreme data, we subdivided fodder range into three percentile categories $(0-33 \%, 36-66 \%$, and $67-100 \%)$ and excluded the highest $\mathrm{C}$ stock and species richness values within each category.

\section{Landscape-scale trade-offs}

Landscape was defined as an area of $\sim 477 \mathrm{~km}^{2}$ that included the CCBR $\left(\sim 132 \mathrm{~km}^{2}\right)$ and an adjacent area within a $5 \mathrm{~km}$ buffer $(\sim 345$ $\left.\mathrm{km}^{2}\right)$, where most of the 55 sites were located. This buffer area was calculated by assuming that the reserve polygon is a perfect rectangle of $20.0 \times 6.6 \mathrm{~km}$. The landscape was subdivided into 0.24 ha plots, because this was the unit in which the data for calculating species richness was available.

We assessed the shape of the efficiency frontiers at the landscape scale by simulating a step-wise landscape deforestation process. This simulation included only two land cover types: old-growth forest and pastures. Although we acknowledge that secondary forest constitutes an important land cover type in the region, it was not included as an alternative choice for inferring the efficiency frontier because insufficient data on species incidence exist for this purpose. We also assumed that the landscape comprised hilly areas only, where fodder production is concentrated (Maass et al. 2005).

Prior to initiating the simulation, we assigned fodder and $\mathrm{C}$ stock values under both old-growth forest and pasture land covers to each plot. Because we attempted to define the efficiency frontier, values were assigned randomly from normal distributions defined by the highest fodder and $\mathrm{C}$ stock values observed among 52 of the 55 sampled sites (points above the 95\% data curve were excluded). The highest values were defined as those above the third quartile for each service and cover type combination. Their mean and standard deviation values were used to define normal distributions (Table 1). We checked that the assigned values were all below the $95 \%$ data frontier. When this was not the case, we coerced the value by using the frontier function to estimate the corresponding $\mathrm{C}$ stock for its assigned fodder level.

Species composition could not be assigned following the same criteria because we had a limited number of sites per cover type from which to adequately estimate species occurrence probabilities. Instead, for old-growth forests, we used published data on the species composition of 210.24 ha old-growth forests plots accounting for 144 tree species (Durán et al. 2006) and calculated the probability of presence for each species within a plot. We then defined the presence/absence of a species in a plot using those probabilities and a random number generator: each time the random number (between 0 and 1 ) was equal or greater to the actual probability of presence of the species, it was designated as present, otherwise it was considered absent. The procedure was repeated for all 144 species and for all the plots across the landscape. For pastures, neither our own data (small sample size) nor other available data (Durán et al. 2006) were adequate for assessing species composition. We therefore did not include pastures in the quantification of species richness in the landscape.

Simulation of the step-wise deforestation process began with a landscape completely covered by old-growth forest. Plots were randomly assigned at locations within or outside the CCBR. The simulation proceeded such that the plots outside the reserve were 
Table 1. Plot level parameter values used for the calculation of landscape-level efficiency frontiers and current landscape efficiency. C stock refers to carbon in above-ground biomass. Fodder refers to biomass in plants of $\mathrm{DBH}<1 \mathrm{~cm}$. Values in parenthesis are sample sizes from which the parameter values were estimated. All values are in Mg ha-1.

\begin{tabular}{|c|c|c|c|c|}
\hline Parameter & Variable & Old-growth forest & Secondary forest & Pasture \\
\hline \multirow[t]{4}{*}{ Mean } & Maximum C stock & $30.84(3)$ & $23.41(4)$ & $4.42(7)$ \\
\hline & Current C stock & $25.82(11)$ & $15.65(14)$ & $2.72(27)$ \\
\hline & Maximum fodder & $0.88(2)$ & $1.62(4)$ & $8.01(7)$ \\
\hline & Current fodder & $0.49(11)$ & $0.87(14)$ & $4.87(27)$ \\
\hline \multirow[t]{4}{*}{ Standard deviation } & Maximum C stock & 1.70 & 4.28 & 0.79 \\
\hline & Current C stock & 4.05 & 6.50 & 1.27 \\
\hline & Maximum fodder & 0.32 & 0.68 & 1.60 \\
\hline & Current fodder & 0.26 & 0.64 & 2.47 \\
\hline
\end{tabular}

deforested first. Only after the landscape outside the reserve was completely converted to pasture, were plots within the reserve considered eligible for deforestation. Plots with potential deforestation were selected on the basis of their ratio of gain in fodder per unit of carbon loss when transformed from old-growth forest to pasture. During each simulation step, the $10 \%$ of the remaining old-growth forest plots with the highest ratio were deforested. Simulation ended when all the landscape was converted to pasture. This procedure allowed us to find the exact frontier for the $\mathrm{C}$ stock-fodder case. For the species-fodder case, however, the procedure generated only an approximation to the exact frontier.

After each simulation step, we calculated landscape-scale fodder, $\mathrm{C}$ stock, and species richness values. Fodder and $\mathrm{C}$ stock values were calculated by simply adding their plot-level values (as a function of the land cover of the plot) across all the plots. Landscape-level species richness was defined as the number of species present in at least $1 / 21$ of the plots across the landscape ( 9455 plots), which corresponds to the minimum species presence probability from Durán et al. (2006). Such a probability implies population sizes of around 10,000 reproductive individuals within the studied area, given tree densities and minimum tree size for flower production in the region (Bullock 2002a, b, Durán 2004). We consider that this level of adult density would be adequate to maintain viable populations of any tree species.

Finally, landscape efficiency frontiers were defined by plotting the values for landscape $\mathrm{C}$ stock and species richness as a function of fodder. The simulation process was repeated 1000 times. Because results from the different draws were very similar, only mean values are presented. All of the analyses were undertaken using $\mathrm{R}$ software (R Development Core Team 2015).

\section{Current landscape fodder supply and $\mathbf{C}$ storage}

We estimated the current landscape-level fodder supply and C stock maintenance based on two independent estimates of current deforestation across the landscape outside the CCBR. A "low deforestation" estimate of $17 \%$ deforestation across the landscape was derived from interpretation of satellite imagery (SánchezAzofeifa et al. 2009). A "high deforestation" estimate of $61 \%$ of the landscape deforested was calculated from the reported perceptions of the landowners regarding deforestation (SánchezAzofeifa et al. 2009, Cohen Salgado 2014).

Within each deforestation scenario, plots were randomly assigned as being covered by forest or pasture. Forest plots were assigned to old-growth or secondary forest cover based on their proportional contribution to total forest cover. We relied on a coarse estimation of secondary forest coverage derived from thirty different landowners' perceptions about the different types of covers present on their properties (F. Mora, unpublished data). A total of $36 \%$ of the forest was estimated as being secondary, i.e., sites that were previously clear-cut for agricultural purposes and then abandoned. Plots within the CCBR were always assigned to old-growth forest cover. Following land cover definition, we assigned each plot its current fodder and $\mathrm{C}$ stock values, using a procedure analogous to that previously described for defining the landscape-level frontier. The mean and standard deviation estimates for fodder and $\mathrm{C}$ stocks used are provided in Table 1. Such parameter estimates were calculated from all of our data, using sites located outside the CCBR; they are assumed to be representative of the current forest and pasture management condition in the region (forest used for cattle ranching and extraction of forest products). We calculated current landscapelevel fodder supply and C-stock maintenance for each of the two deforestation estimates by aggregating the corresponding plotlevel values for each service across the whole landscape.

Finally, we assessed how different management activities could drive the landscape service supply toward the efficiency frontier by simulating three hypothetical but feasible, socially desirable, management scenarios (always assuming no further land cover change):

- Secondary forest regeneration allowed: secondary forests reach their maximum $\mathrm{C}$ stock and fodder values (Table 1) by allowing regrowth, whereas old-growth forests and pastures continue to be used under current conditions.

- Pasture management through continued current practices: pasture plots are managed through current landowners' practices known to increase fodder productivity, such as repeated slash and burn events, so that the observed fodder values attain their maximum (Table 1) after three decades of continued management (Trilleras et al. 2015).

- Secondary forest regeneration and pasture management through continued current practices: this is a combination of the two previous management conditions.

We did not assess current species richness at the landscape scale given the data limitations in terms of adequately estimating species occurrence probabilities under both old-growth (not 
under conservation) and secondary forest sites, especially considering the existence of successional niches among tropical trees and the rapid change in species composition along succession in this TDF (Letcher et al. 2015, Mora et al. 2015).

\section{RESULTS}

\section{Plot-level trade-offs}

We found strong trade-offs between fodder and C stock, and between fodder and species richness, at the site level. The exclusion of the $5 \%$ most extreme data clearly modified the position of the frontiers, particularly for $\mathrm{C}$ stock, although it did not qualitatively change their shape (Fig. 2). A step decrease in both C stocks and richness was found at fodder values $\sim 2 \mathrm{Mg} \mathrm{ha}^{-1}$ for the $95 \%$ data fit. The efficiency frontier then stabilized at 5.6 $\mathrm{Mg} \mathrm{C} \mathrm{ha}^{-1}$ and at 4 species (Table 2$)$. The maximum attainable $\mathrm{C}$ stock $\left(\operatorname{Serv}_{\min }+\right.$ $S e r v_{\text {max }}$ ) dropped from 42.3 to $33.4 \mathrm{Mg} \mathrm{ha}^{-1}$ after the exclusion of extreme data, and richness decreased from 23.0 to 19.3 species (Fig. 2b, Table 2).

Fig. 2. Plot level efficiency frontiers between (a) fodder and C stock in the above-ground living biomass of trees, and (b) fodder and rarified tree species richness for tropical dry forests and pasture sites within and adjacent to the Chamela-Cuixmala Biosphere Reserve. The fitted efficiency frontiers derived when using the complete dataset are indicated by discontinuous lines, and the efficiency frontier derived when excluding the most extreme $5 \%$ of $\mathrm{C}$ stock or species richness data (hollow points) are indicated by continuous lines.

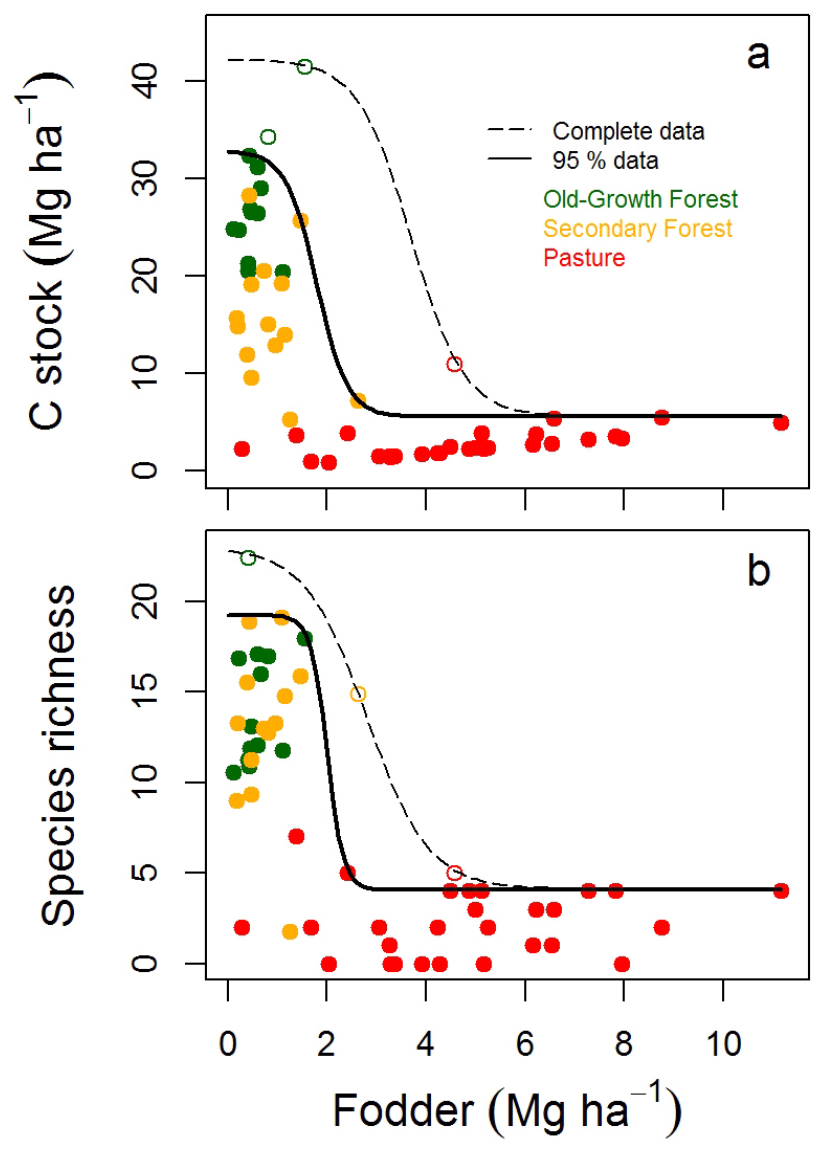

Table 2. Parameter estimates for the fit of the logistic function to model the site-level efficiency frontiers.

\begin{tabular}{llcccc}
\hline \hline Serv $_{\text {frant }}$ & Type of fit & Serv $_{\min }$ & Serv $_{\max }$ & $\mathrm{a}$ & $\mathrm{b}$ \\
\hline C stock & Complete data & 5.56 & 36.7 & 3.70 & -0.53 \\
& $95 \%$ data & 5.56 & 27.8 & 1.79 & -0.31 \\
\multirow{2}{*}{ Species richness } & Complete data & 4.12 & 18.9 & 2.81 & -0.62 \\
& $95 \%$ data & 4.06 & 15.2 & 2.00 & -0.17 \\
\hline
\end{tabular}

Old-growth forests had the highest values of $\mathrm{C}$ stock and the lowest fodder values, whereas pastures showed the opposite trend (Table 1). Secondary forest showed reduced $\mathrm{C}$ stocks in relation to old-growth forests and a slight increase in fodder availability (Fig. 2a, Table 1). The same general pattern was found for species richness, although secondary forests showed similar or even higher richness than old-growth forests (Fig. 2b). C stocks and richness were highly correlated (Spearman rho $=0.87, S=3710$, $\mathrm{P}<0.001$; Appendix 1).

\section{Landscape-level trade-offs}

Trade-offs at the landscape level were much less pronounced than those at the plot scale. The shape of the landscape-level efficiency frontier for fodder and $\mathrm{C}$ stock was slightly concave (Fig. 3a). Along the efficiency frontier, the maximum $\mathrm{C}$ stock was $1.47 \mathrm{Tg}$ when the landscape was completely covered by old-growth forests, and associated with a minimum fodder value of $41.8 \mathrm{Gg}$ (point "a" in Fig. 3a). The reserve accounted for $37.9 \%$ of this maximum C stock (0.56 Tg C; point "d" in Fig. 3b). Under complete deforestation, only $14.2 \%(0.21 \mathrm{Tg} \mathrm{C})$ of the $\mathrm{C}$ stock was conserved, and a maximum value of $382 \mathrm{Gg}$ of fodder was reached (point "e" in Fig. 3a).

The efficiency frontier for fodder and woody species richness was strictly concave (Fig. 3b). The maximum number of species estimated along the frontier for the whole landscape was 135 and was found under complete forest cover (point "a" in Fig. 3b). The biosphere reserve plays a significant role in conserving such diversity because an average of 87 species (64\% of maximum value) is conserved solely by the reserve if maximum efficiency is assumed (point "d" in Fig. 3b). No species were found under complete deforestation because we did not include pastures in the quantification of species richness at the landscape scale (point "e" in Fig. 3b).

\section{Landscape-level current fodder and $\mathbf{C}$ stocks}

Along the efficiency frontier, the two current deforestation estimates were associated with contrasting levels of $\mathrm{C}$ stocks at the landscape scale. Between $10.2 \%$ and $37.4 \%$ of the $\mathrm{C}$ stock was lost under low and high estimates of current deforestation, respectively (Fig 3a, points "b" and "c"). In contrast, no difference in species richness along the frontier was observed between deforestation estimates; in both cases a reduction of only 14 species $(10.4 \%)$ from the maximum species richness was observed (Fig 3b, points "b" and "c").

Current landscape-level fodder availability and C stock were found to be far from their optimal condition. Under low deforestation, $57 \mathrm{Gg}$ of fodder and $1.04 \mathrm{Tg}$ of $\mathrm{C}$ stock were estimated to be provided by the entire landscape (Fig. 3a, point " $b_{\text {curr }}$ "), corresponding to $58.9 \%$ and $79.0 \%$ of values along the 
Fig. 3. Landscape-level efficiency frontiers between (a) fodder and $\mathrm{C}$ stock in above-ground living biomass of trees, and (b) fodder and rarified tree species richness for the ChamelaCuixmala Biosphere Reserve and adjacent areas within a five $\mathrm{km}$ buffer. The black continuous line depicts the efficiency frontier when deforestation goes from a completely forested (point a) to a completely deforested landscape outside the CCBR (point d). The discontinuous portion represents the continued efficiency frontier if deforestation extends within the reserve until deforestation of the whole landscape (point e). Points $\mathrm{b}$ and $\mathrm{c}$ represent the maximum efficiency for low $(17 \%)$ and high (61\%) current deforestation estimates, respectively. Filled points (bcurr and ccurr) are estimates of current service supply under such current deforestation estimates and current management conditions. Other filled symbols represent service supply values under hypothetical management conditions: secondary forest regrowth allowed (diamonds), maximum pasture (triangles), and secondary forest regrowth allowed plus maximum pasture efficiency (triangles). Current service estimates and those under hypothetical management conditions consider that $36 \%$ of the forest is secondary.

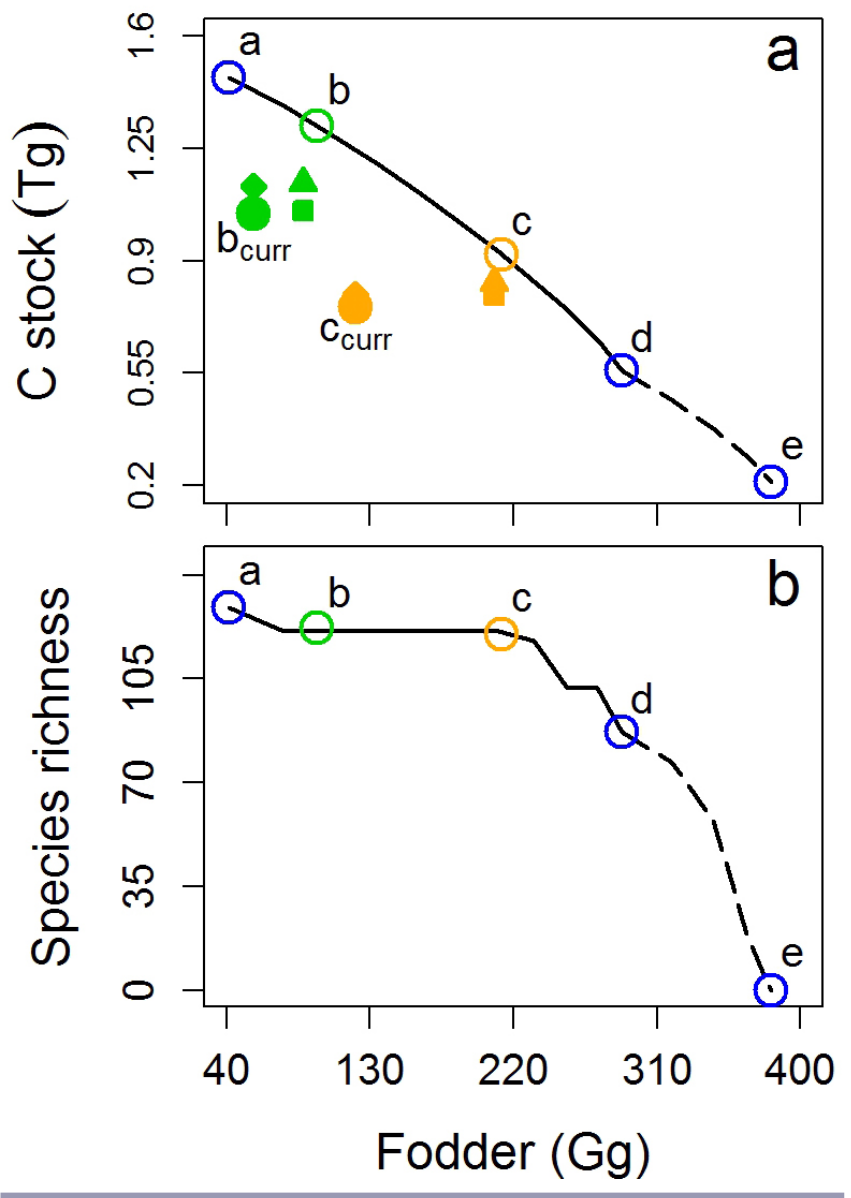

frontier (Fig. 3a, point "b"). Under high deforestation, $121 \mathrm{Gg}$ of fodder and $0.75 \mathrm{Tg} \mathrm{C}$ were estimated (Fig. 3a, point " $\mathrm{c}_{\text {curr }}$ "), corresponding to $57.0 \%$ and $82.0 \%$ of the values along the efficiency frontier (Fig. 3a, point "c").
All three management scenarios assessed were associated with shifting current service supply toward the landscape-scale efficiency frontier, although the relative effect of each depended on deforestation condition. Secondary forest regrowth was related to a greater increase in $\mathrm{C}$ stocks under low deforestation $(0.09 \mathrm{Tg}$ C) than under high deforestation $(0.04 \mathrm{Tg} \mathrm{C}$; Fig. 3a), while causing only marginal changes in fodder values $(<1 \mathrm{Gg})$. In contrast, increased pasture efficiency increased fodder supply by 31.2 and $87.0 \mathrm{Gg}$ under low and high deforestation estimates, respectively. Carbon stocks also increased under this scenario, with 0.01 and $0.04 \mathrm{Tg} \mathrm{C}$ added under low and high deforestation estimates, respectively. The increase in $\mathrm{C}$ stocks for the high deforestation estimate was therefore the same under secondary forest regrowth and increased pasture efficiency scenarios (Fig. 3a). The combination of both management strategies substantially improved both fodder supply and C storage, particularly under the high deforestation estimate, for which the resulting distance to the frontier was shorter when compared to the lower deforestation estimate (Fig. 3a).

\section{DISCUSSION}

\section{Efficiency frontiers at two spatial scales}

The striking differences in the form of the efficiency frontier between site and landscape scales suggest the existence of differential processes underpinning service supply at contrasting spatial scales. The convex efficiency frontiers found at the plot scale most probably reflect the role of light as a limiting resource for plant growth. Forest clearance is currently a requirement for increased fodder availability of introduced, light-demanding grasses, as the steep decline in $\mathrm{C}$ stocks and species richness at low fodder levels suggests. Furthermore, if shrubs and trees are allowed to grow on pastures, a rapid recovery of the canopy cover occurs in just a few years (Lebrija-Trejos et al. 2008, Mora et al. 2015). Increased canopy cover reduces light availability in the understory (Lebrija-Trejos et al. 2011, Pineda-García et al. 2013), thereby excluding those grasses. Peasants are clearly aware of this trade-off and invest time, energy, and money in periodic slash and burn of their pastures to avoid the growth of woody species (Burgos and Maass 2004, Trilleras et al. 2015). Because species richness is partially related to individual density (Gotelli and Colwell 2001), the strong reduction in tree density associated with forest clearance also implies a steep decline in tree species richness.

The change in shape of the efficiency frontier when scaling to the landscape arises from both the manner in which services are aggregated across sites and from differences in the level of service supply redundancy among these sites. Carbon storage is not a redundant service, i.e., the loss of $\mathrm{C}$ storage through forest clearance in some plots is not compensated by keeping other plots forested. The efficiency frontier for $\mathrm{C}$ stocks therefore reflects the way plots are selected for deforestation: the typical concave curve arises from first deforesting those plots with the highest pasture productivity and the lowest carbon loss. An analogous process has been used for defining other efficiency frontier curves (Polasky et al. 2008, Cavender-Bares et al. 2015). The fact that the curve is only slightly concave is due to the relatively similar fodder gain to carbon loss ratios across plots. The more pronounced concavity in the case of the species richness frontier occurs because this is a redundant service, i.e., remnant forests buffer the loss of species 
throughout most of the deforestation process. Only when an important portion of the forest has been lost does the proportion of plots in which species are present fall below the defined extinction threshold. Such patterns have also been described for other terrestrial and aquatic environments (Polasky et al. 2008, Brown and Mumby 2014).

Our data confirm the well-known trade-off between forest conservation, which accounts for most of the $\mathrm{C}$ storage and species richness, and the livelihood of the peasants that depend on deforestation and livestock production (Cohen Salgado 2014, Salmerón 2015). Nevertheless, cattle ranching provides very low economic benefits in this area and can even cause economic losses to the peasants (Salmerón 2015). Continued cattle ranching may be sustained by the rationale that livestock is perceived as a "savings account," a useful source of ready cash in the case of financial emergencies (IFAD 2004, Gerritsen et al. 2007, Casas et al. 2008), or by some kind of historical "inertia" following decades of governmental programs promoting livestock production (Maass et al. 2005, Borrego and Skutsch 2014) and for cultural reasons related to social prestige or respect for being "rancheros" (Shadow 2002, Gerritsen et al. 2007). The result is that, as deforestation has advanced, the public benefit of C storage has been lost, sometimes without obtaining the private benefit of economic returns from livestock production. Alternatives aimed at reducing the strength of the observed trade-offs and increasing economic revenues to households are urgently required.

\section{Limits to current service supply}

We found that service supply at both site and landscape scales is clearly below the maximum feasible levels described by the shape of the efficiency frontier. Both the biophysical characteristics of the area and the current management regime contribute to this pattern. The heterogeneity of the landscape caused by the topographical gradients in soil moisture availability contributes to important differences in C stocks (Jaramillo et al. 2003), fodder (Trilleras et al. 2015), and species richness (Balvanera et al. 2002) across sites. Poor pasture maintenance may lead to reduced fodder supply, especially in sites with higher productivity that require more frequent burns to foster pasture growth and prevent woody encroachment (Trilleras et al. 2015). Furthermore, C stocks were found to be higher in the old-growth forests within the reserve than in those outside of the reserve, possibly due to forest degradation from the extraction of forest products and cattle grazing (Burgos and Maass 2004, Cohen Salgado 2014). Similar degradation issues are present across other tropical dry forest regions (Chaturvedi et al. 2012, Ribeiro et al. 2015).

Temporal lags in the response of services to natural disturbances or human interventions can also explain nonefficient supply levels. When two services are trading off, achieving the maximum level of the preferred service commonly implies a time lag (Cavender-Bares et al. 2015) associated with reconfiguration of the biophysical basis on which such services depend. This could be the case with forage production, which has been found to increase as pastures get older (Trilleras et al. 2015). A much longer time lag occurs for the recovery of $\mathrm{C}$ stocks through forest regeneration from human disturbances: it takes an average of 66 years to attain values comparable to those of the conserved forest (Poorter et al. 2016).
The historical lack of coordination between different government programs that promote conflicting land management objectives may also prevent achieving sustainability. Cattle-ranching programs have encouraged forest conversion to pasture (Maass et al. 2005, Griscom and Ashton 2011). On the other hand, current environmental programs, such as payment for environmental services (PES) or the establishment of protected areas, limit the use of resources and still promote a "do not touch" management approach. The simultaneous and uncoordinated implementation of these policies in the territory encourages peasants to develop inefficient management practices.

\section{Increasing service supply through alternative management strategies}

Our simulations suggest that the degree of landscape transformation should be considered in the selection of the management strategy aimed at increasing service supply. Under low deforestation, permitting the complete recovery of secondary forests through succession shifts service supply closer to the efficiency frontier. High forest recovery rates in the region enable such an alternative (Mora et al. 2015, Poorter et al. 2016). However, secondary forests are commonly cleared again for pasture establishment. Financial mechanisms like REDD+, which explicitly account for $\mathrm{C}$ savings and biodiversity benefits from deforestation avoidance (Phelps et al. 2012), could encourage secondary forest regrowth by providing an alternative household income (Borrego and Skutsch 2014).

In contrast, the best option for moving toward the efficiency frontier under high deforestation conditions seems to be increasing pasture productivity. In the Chamela-Cuixmala region, increased pasture productivity is currently achieved through a higher frequency of slash and burn events (Trilleras et al. 2015), although it could come at the cost of long-term negative effects on nutrient cycling, soil nutrient stocks, and fodder quality (Lawrence et al. 2007, García-Oliva and Jaramillo 2011, Trilleras et al. 2015). Alternatives for increased livestock production in the tropics include pasture enrichment with native forage trees. This has proven to be successful in other regions with similar climatic conditions (Barrance et al. 2003, Dagang and Nair 2003, Murgueitio et al. 2011) and is being tested (C. Gonzalez, personal communication) or has already been implemented by some of the peasants in the Chamela-Cuixmala region (F. Mora, personal observation). Also, its adoption is favored under high deforestation scenarios (Kaimowitz and Angelsen 2008). Furthermore, the presence of native forage trees would increase $\mathrm{C}$ stocks and favor tree diversity in pastures without compromising fodder supply (Barrance et al. 2003, Dagang and Nair 2003), therefore softening their local trade-off.

When used in combination, intensification of pasture production and permitted secondary forest regeneration can significantly contribute to increasing service supply and to reduce trade-offs between forest maintenance and people's livelihoods (Latawiec et al. 2015). Interestingly, our simulations suggest that this does not take service supply to the efficiency frontier. The management regime of old-growth forests is also at stake. When old-growth forests are subjected to timber extraction and cattle grazing within the forest, a reduction takes place in both carbon stocks and species richness (Chaturvedi et al. 2012, Ribeiro et al. 2015). Secondary and old-growth forests are the most important sources 
of fodder when pastures are depleted, and timber extraction may contribute to family income (Cohen Salgado 2014, Salmeróln 2015). Preventing or reverting forest degradation is thus key to reaching the efficiency frontier. The role of forest degradation is increasingly being addressed by REDD+, and its financial incentives are perceived by the peasants as suitable for preventing and reverting forest degradation (Skutsch et al. 2015).

Addressing the trade-offs documented here through changes in management regime and technologies faces the additional challenge that the peasants' methods of managing their land have been deeply entrenched over time. Communicating and promoting the adoption of new ideas is the seed with which to foster social change (Rogers 2003). Dissemination of the still few local alternative management experiences, along with sharing results from scientific studies regarding sustainable ecosystem management, are now taking place through workshops, field experiments, and collaborative projects between the peasants and scientists. Strengthening the existing social network and opening more spaces for information exchange seem to be the pathways to satisfy peasants' needs and secure their livelihoods while simultaneously maintaining tropical dry forests in such conditions that their capacities to supply ecosystem services, including $\mathrm{C}$ storage and biodiversity, are not irreversibly damaged.

\section{CONCLUSIONS}

Under the efficiency frontier framework, achieving sustainability is related to moving service supply toward the efficiency frontier, with the particular position along the frontier defined by the needs, preferences, and values of stakeholders (Cavender-Bares et al. 2015). By applying this framework to the analysis of service supply in a tropical dry forest landscape, we have shown that, although strong trade-offs between forage production for cattle and carbon stocks maintenance or species conservation exist, it is still possible to increase the supply of these services from their current suboptimal level by modifying the management of both pastures and forests.

Allowing full recovery of secondary forests while enriching pastures with native forage trees emerge as ideal management options by which to increase carbon storage, promote landscapescale biodiversity conservation, and sustain rural livelihoods. For this purpose, economic incentives to maintain current forest cover (and therefore $\mathrm{C}$ stocks and biodiversity conservation), along with technical support for alternative management practices should be given priority. The prevalent trade-offs between forest maintenance for carbon storage and biodiversity and rural livelihoods that occur in the tropics can be addressed through technological changes and support from financial incentives. The insights gained here contribute toward the sustainability of tropical landscapes.

Responses to this article can be read online at: http://www.ecologyandsociety.org/issues/responses. $\mathrm{php} / 8691$

\section{Acknowledgments:}

The ideas developed here have emerged from the past 15 years of interdisciplinary collaboration with many colleagues working within the Chamela-Cuixmala region, and this synthesis was fostered by workshops held at the National Center for Ecological Analysis and Synthesis. Financial support for this work was obtained from funding through PAPIIT IN211114, SEP-CONACYT 2012-179045 and SEP-CONACYT 2015-255544 to PB, and PAPIIT IN300813 to $A C$. We acknowledge the support of the Chamela Biological Station (UNAM) to undertake fieldwork and all of the local stakeholders who contributed with their expertise.

\section{LITERATURE CITED}

Achard, F., R. Beuchle, P. Mayaux, H.-J. Stibig, C. Bodart, A. Brink, S. Carboni, B. Desclée, F. Donnay, H. D. Eva, A. Lupi, R. Raši, R. Seliger, and D. Simonetti. 2014. Determination of tropical deforestation rates and related carbon losses from 1990 to 2010. Global Change Biology 20(8):2540-2554. http://dx.doi. org/10.1111/gcb.12605

Anderson-Teixeira, K. J., P. K. Snyder, T. E. Twine, S. V. Cuadra, M. H. Costa, and E. H. DeLucia. 2012. Climate-regulation services of natural and agricultural ecoregions of the Americas. Nature Climate Change 2(3):177-181. http://dx.doi.org/10.1038/ nclimate1346

Balvanera, P., A. Castillo, and M. J. Martínez-Harms. 2011. Ecosystem services in seasonally dry tropical forests. Pages 259-277 in R. Dirzo, H. S. Young, H. A. Mooney, and G. Ceballos, editors. Seasonally dry tropical forests: ecology and conservation. Island, Washington, D.C., USA. http://dx.doi.org/10.5822/978-$\underline{1-61091-021-7 \quad 15}$

Balvanera, P., E. Lott, G. Segura, C. Siebe, and A. Islas. 2002. Patterns of $\beta$-diversity in a Mexican tropical dry forest. Journal of Vegetation Science 13(2):145-158. http://dx.doi.org/10.1111/ j.1654-1103.2002.tb02034.x

Barrance, A. J., L. Flores, E. Padilla, J. E. Gordon, and K. Schreckenberg. 2003. Trees and farming in the dry zone of southern Honduras I: campesino tree husbandry practices. Agroforestry Systems 59:97-106. http://dx.doi.org/10.1023/ A:1026347006022

Beale, I. F. 1973. Tree density effects on yields of herbage and tree components in south west Queensland mulga (Acacia aneura F. Muell.) scrub. Tropical Grasslands 7(1):135-142.

Borrego, A., and M. Skutsch. 2014. Estimating the opportunity costs of activities that cause degradation in tropical dry forest: implications for REDD+. Ecological Economics 101:1-9. http:// dx.doi.org/10.1016/j.ecolecon.2014.02.005

Brown, C. J., and P. J. Mumby. 2014. Trade-offs between fisheries and the conservation of ecosystem function are defined by management strategy. Frontiers in Ecology and the Environment 12(6):324-329. http://dx.doi.org/10.1890/130296

Bullock, S. H. 2002a. Cordia elaeagnoides DC. (Boraginaceae). Barcino. Pages 151-153 in F. A. Noguera, J. H. Vega, A. N. García- 
Aldrete, and M. Quesada, editors. Historia Natural de Chamela. Instituto de Biología, Universidad Nacional Autónoma de México, México D.F., México.

Bullock, S. H. 2002b. Jacaratia mexicana A. DC. (Caricaceae). Bonete. Pages 155-157 in F. A. Noguera, J. H. Vega, A. N. GarcóaAldrete, and M. Quesada, editors. Historia Natural de Chamela. Instituto de Biología, Universidad Nacional Autónoma de México, México D.F., México.

Burgos, A., and J. M. Maass. 2004. Vegetation change associated with land-use in tropical dry forest areas of Western Mexico. Agriculture, Ecosystems and Environment 104(3):475-481. http:// dx.doi.org/10.1016/j.agee.2004.01.038

Casas, A., S. Rangel-Landa, I. Torres, E. Peréz-Negrón, L. Solís, F. Parra, A. Delgado, J. Blancas, B. Farfán-Heredia, and A. Moreno-Calles. 2008. In situ management and conservation of plant resources in the Tehuacán-Cuicatlán Valley, México: an ethnobotanical and ecological approach. Pages 1-25 in U. De Albuquerque and M. Alves-Ramos, editors. Current topics in ethnobotany. Research Signpost, Kerala, India.

Castillo, A., A. Magaña, A. Pujadas, L. Martínez, and C. Godínez. 2005. Understanding the interaction of rural people with ecosystems: a case study in a tropical dry forest of Mexico. Ecosystems 8(6):630-643. http://dx.doi.org/10.1007/s10021-005-0127-1

Cavender-Bares, J., S. Polasky, E. King, and P. Balvanera. 2015. A sustainability framework for assessing trade-offs in ecosystem services. Ecology and Society 20(1):17. http://dx.doi.org/10.5751/ $\underline{\text { es-06917-200117 }}$

Chaturvedi, R. K., A. S. Raghubanshi, and J. S. Singh. 2012. Effect of grazing and harvesting on diversity, recruitment and carbon accumulation of juvenile trees in tropical dry forests. Forest Ecology and Management 284:152-162. http://dx.doi.org/10.1016/ j.foreco.2012.07.053

Cohen Salgado, D. 2014. Estrategias de manejo de recursos naturales en un ejido aledaño a la Reserva de la Biósfera ChamelaCuixmala, Jalisco. BSc. Thesis. Universidad Nacional Autónoma de México, Morelia, México.

Cotler, H., E. Durán, and C. Siebe. 2002. Caracterización morfoedafológica y calidad de sitio de un bosque tropical caducifolio. Pages 17-79 in F. A. Noguera, J. H. Vega, A. N. García-Aldrete, and M. Quesada, editors. Historia Natural de Chamela. Instituto de Biología, Universidad Nacional Autónoma de México, México D.F., México.

Dagang, A. B. K., and P. K. R. Nair. 2003. Silvopastoral research and adoption in Central America: recent findings and recommendations for future directions. Agroforestry Systems 59:149-155. http://dx.doi.org/10.1023/A:1026394019808

de Albuquerque, U. P., L. de H. C. Andrade, and A. C. O. de Silva. 2005. Use of plant resources in a seasonal dry forest (Northeastern Brazil). Acta Botanica Brasilica 19:27-38. http:// dx.doi.org/10.1590/S0102-33062005000100004

Durán, E. 2004. Estructura, diversidad y mortalidad del componente arboreo en un mosaico ambiental de Chamela, Jalisco. Dissertation. Universidad Nacional Autónoma de México, México D.F., México.
Durán, E., P. Balvanera, E. Lott, G. Segura, A. Pérez-Jiménez, Á. Íslas, and M. Franco. 2002. Estructura, composición y dinámica de la vegetación. Pages 443-472 in F. A. Noguera, J. H. Vega, A. N. García-Aldrete, and M.Quesada, editors. Historia natural de Chamela. Instituto de Biología, Universidad Nacional Autínoma de México, México D.F., México.

Durán, E., J. Meave, E. J. Lott, and G. Segura. 2006. Structure and tree diversity patterns at the landscape level in a Mexican tropical deciduous forest. Boletín de la Sociedad Botánica de México 79:43-60.

García-Oliva, F., A. Camou, and J. M. Maass. 2002. El clima de la region central de la costa del Pacífico mexicano. Pages 3-10 in F. A. Noguera, J. H. Vega, A. N. García-Aldrete, and M. Quesada, editors. Historia natural de Chamela. Instituto de Biología, Universidad Nacional Autónoma de México, Mexico D.F., México.

García-Oliva, F., and V. J. Jaramillo. 2011. Impact of anthropogenic transformation of seasonally dry tropical forests on ecosystem biogeochemical processes. Pages 159-172 in R. Dirzo, H. S. Young, H. A. Mooney, and G. Ceballos, editors. Seasonally dry tropical forests: ecology and conservation. Island/ Center for Resource Economics, Washington, D.C., USA. http:// dx.doi.org/10.5822/978-1-61091-021-7 10

Gerritsen, P., J. Rosales, A. Moreno, and D. Louette. 2007. Ganadería y sociedad: los sistemas productivos ganaderos en la Sierra de Manantlán. Pages 27-52 in L. M. Martínez Rivera and P. R. W. Gerritsen, editors. Estado actual y perspectivas de la ganadería extensiva en la Sierra de Manantlán, en el occidente de México. Universidad de Guadalajara, Guadalajara, México.

Gilroy, J. J., P. Woodcock, F. A. Edwards, C. Wheeler, C. A. Medina Uribe, T. Haugaasen, and D. P. Edwards. 2014. Optimizing carbon storage and biodiversity protection in tropical agricultural landscapes. Global Change Biology 20(7):2162-2172. http://dx.doi.org/10.1111/gcb.12482

Gotelli, N. J., and R. K. Colwell. 2001. Quantifying biodiversity: procedures and pitfalls in the measurement and comparison of species richness. Ecology Letters 4(4):379-391. http://dx.doi. org/10.1046/j.1461-0248.2001.00230.x

Griscom, H. P., and M. S. Ashton. 2011. Restoration of dry tropical forests in Central America: a review of pattern and process. Forest Ecology and Management 261(10):1564-1579. http://dx.doi.org/10.1016/j.foreco.2010.08.027

Harvey, C. A., and W. A. Haber. 1998. Remnant trees and the conservation of biodiversity in Costa Rican pastures. Agroforestry Systems 44:37-68. http://dx.doi.org/10.1023/ A:1006122211692

International Fund for Agricultural Development (IFAD). 2004. Livestock services and the poor: a global initiative. Collecting, coordinating and sharing experiences. International Fund for Agricultural Development, Rome, Italy. [online] URL: https:// www.ifad.org/documents/10180/831c52c2-2ee2-4ff0-8d59-6aef6aa6dc97

Jaramillo, V. J., J. B. Kauffman, L. Rentería-Rodríguez, D. L. Cummings, and L. J. Ellingson. 2003. Biomass, carbon, and nitrogen pools in Mexican tropical dry forest landscapes. Ecosystems 6(7):609-629. http://dx.doi.org/10.1007/s10021-002-0195-4 
Kaimowitz, D., and A. Angelsen. 2008. Will livestock intensification help save Latin America's tropical forests? Journal of Sustainable Forestry 27(1-2):6-24. http://dx.doi. org/10.1080/10549810802225168

King, E. G., J. Cavender-Bares, P. Balvanera, T. H. Mwampamba, and S. Polasky. 2015. Tradeoffs in ecosystem services and varying stakeholder preferences: evaluating conflicts, obstacles, and opportunities. Ecology and Society 20(3):25. http://dx.doi. org/10.5751/ES-07822-200325

Lambin, E. F., H. J. Geist, and E. Lepers. 2003. Dynamics of landuse and land-cover change in tropical regions. Annual Review of Environment and Resources 28(1):205-241. http://dx.doi. org/10.1146/annurev.energy.28.050302.105459

Latawiec, A. E., B. B. N. Strassburg, P. H. S. Brancalion, R. R. Rodrigues, and T. Gardner. 2015. Creating space for large-scale restoration in tropical agricultural landscapes. Frontiers in Ecology and the Environment 13(4):211-218. http://dx.doi. org/10.1890/140052

Lawrence, D., P. D’Odorico, L. Diekmann, M. DeLonge, R. Das, and J. Eaton. 2007. Ecological feedbacks following deforestation create the potential for a catastrophic ecosystem shift in tropical dry forest. Proceedings of the National Academy of Sciences 104 (52):20696-20701. http://dx.doi.org/10.1073/pnas.0705005104

Lebrija-Trejos, E., F. Bongers, E. A. Pérez-García, and J. A. Meave. 2008. Successional change and resilience of a very dry tropical deciduous forest following shifting agriculture. Biotropica 40(4):422-431. http://dx.doi.org/10.1111/j.1744-7429.2008.00398. $\underline{\mathrm{X}}$

Lebrija-Trejos, E., E. A. Pérez-García, J. A. Meave, L. Poorter, and F. Bongers. 2011. Environmental changes during secondary succession in a tropical dry forest in Mexico. Journal of Tropical Ecology 27(5):477-489. http://dx.doi.org/10.1017/s0266467411000253

Letcher, S. G., J. R. Lasky, R. L. Chazdon, N. Norden, S. J. Wright, J. A. Meave, E. A. Pérez-García, R. Muñoz, E. Romero-Pérez, A. Andrade, J. L. Andrade, P. Balvanera, J. M. Becknell, T. V. Bentos, R. Bhaskar, F. Bongers, V. Boukili, P. H. S. Brancalion, R. G. César, D. A. Clark, D. B. Clark, D. Craven, A. DeFrancesco, J. M. Dupuy, B. Finegan, E. González-Jimínez, J. S. Hall, K. E. Harms, J. L. Hernández-Stefanoni, P. Hietz, D. Kennard, T. J. Killeen, S. G. Laurance, E. E. Lebrija-Trejos, M. Lohbeck, M. Martínez-Ramos, P. E. S. Massoca, R. C. G. Mesquita, F. Mora, R. Muscarella, H. Paz, F. Pineda-García, J. S. Powers, R. Quesada-Monge, R. R. Rodrigues, M. E. Sandor, L. SanaphreVillanueva, E. Schüller, N. G. Swenson, A. Tauro, M. Uriarte, M. van Breugel, O. Vargas-Ramírez, R. A. G. Viani, A. L. Wendt, and G. Bruce Williamson. 2015. Environmental gradients and the evolution of successional habitat specialization: a test case with 14 neotropical forest sites. Journal of Ecology 103:1276-1290. http://dx.doi.org/10.1111/1365-2745.12435

Maass, J. M., P. Balvanera, A. Castillo, G. C. Daily, H. A. Mooney, P. Ehrlich, M. Quesada, A. Miranda, V. J. Jaramillo, F. GarcíaOliva, A. Martínez-Yrizar, H. Cotler, J. López-Blanco, A. PérezJiménez, A. Búrquez, C. Tinoco, G. Ceballos, L. Barraza, R. Ayala, and J. Sarukhan. 2005. Ecosystem services of tropical dry forests: Insights from long-term ecological and social research on the Pacific Coast of Mexico. Ecology and Society 10(1):17. [online]
URL: http://www.ecologyandsociety.org/vol10/iss1/art17/ http:// dx.doi.org/10.5751/es-01219-100117

Maass, J. M., C. F. Jordan, and J. Sarukhan. 1988. Soil erosion and nutrient losses in seasonal tropical agroecosystems under various management techniques. Journal of Applied Ecology 25 (2):595-607. http://dx.doi.org/10.2307/2403847

Martínez-Harms, M. J. 2010. Cuantificación y mapeo de servicios ecosistémicos en una cuenca mexicana: implicaciones para su conservación y manejo. Thesis. Universidad Nacional Autónoma de México, Morelia, México.

Martínez-Ramos, M., L. Barraza, P. Balvanera, J. Benítez, F. Bongers, A. Castillo, A. Cuarón, G. Ibarra, H. Paz-Hernández, A. Pérez-Jiménez, M. Quesada, D. R. Pérez-Salicrup, G. A. Sánchez-Azofeifa, J. E. Schondube, K. Stoner, J. A. Díaz, K. Boege, E. Del Val, M. E. F. Carrillo, I. Suazo-ortuño, L. D. Ávila-, M. Álvarez, M. Cano, J. Castillo, O. Chaves, E. De la Peña, A. Corzo, C. Godínez, A. P. Gómez, A. González, B. Fuentealba, W. Gudiño, O. Hernández, M. Lobeck, C. Manrique, S. MazaVillalobos, M. Méndez, F. Mora-Ardila, C. Muench, P. Cristina, L. Pinzón, M. E. Páramo, F. Pineda, A. Ricaño, M. Rocha, J. Rodríguez-Velázquez, N. Schroeder, J. Trilleras-Motha, M. Van Breugel, P. Van Der Sleen, E. Villa, and I. Zermeño. 2012. Manejo de bosques tropicales: bases científicas para la conservación, restauración y aprovechamiento de ecosistemas en paisajes rurales. Investigación Ambiental, Ciencia y Política Pública 4 (2):111-129.

Martínez-Yrízar, A., J. Sarukhan, A. Pérez-Jimínez, E. Rincón, J. M. Maass, A. Solís-Magallanes, and L. Cervantes. 1992. Aboveground phytomass of a tropical deciduous forest on the coast of Jalisco, México. Journal of Tropical Ecology 8(01):87-96. http:// dx.doi.org/10.1017/s0266467400006131

Maza-Villalobos, S., P. Balvanera, and M. Martínez-Ramos. 2011. Early regeneration of tropical dry forest from abandoned pastures: contrasting chronosequence and dynamic approaches. Biotropica 43(6):666-675. http://dx.doi.org/10.1111/ j.1744-7429.2011.00755.x

McKean, M. A. 2000. Common property: what is it, what is it good for, and what makes it work? Pages 27-55 in C. C. Gibson, M. A. McKean, and E. Ostrom, editors. People and forests: communities, institutions, and governance. MIT Press, Cambridge, Massachusetts, USA.

Mora, F., M. Martínez-Ramos, G. Ibarra-Manríquez, A. PérezJimínez, J. Trilleras, and P. Balvanera. 2015. Testing chronosequences through dynamic approaches: time and site effects on tropical dry forest succession. Biotropica 47(1):38-48. http://dx.doi.org/10.1111/btp.12187

Murgueitio, E., Z. Calle, F. Uribe, A. Calle, and B. Solorio. 2011. Native trees and shrubs for the productive rehabilitation of tropical cattle ranching lands. Forest Ecology and Management 261(10):1654-1663. http://dx.doi.org/10.1016/j.foreco.2010.09.027

Oksanen, J., F. G. Blanchet, R. Kindt, P. Legendre, P. R. Minchin, R. B. O'Hara, G. L. Simpson, P. Solymos, H. H. Stevens, and H. Wagner. 2011. Vegan: community ecology package. R package version 2.0-2. R Foundation, Vienna, Austria. [online] URL: https://cran.r-project.org/ 
Phelps, J., E. L. Webb, and W. M. Adams. 2012. Biodiversity cobenefits of policies to reduce forest-carbon emissions. Nature Climate Change 2:497-503. http://dx.doi.org/10.1038/nclimate1462

Pineda-García, F., H. Paz, and F. C. Meinzer. 2013. Drought resistance in early and late secondary successional species from a tropical dry forest: the interplay between xylem resistance to embolism, sapwood water storage and leaf shedding. Plant, Cell and Environment 36(2):405-418. http://dx.doi.org/10.1111/ j.1365-3040.2012.02582.x

Polasky, S., E. Nelson, J. Camm, B. Csuti, P. Fackler, E. Lonsdorf, C. Montgomery, D. White, J. Arthur, B. Garber-Yonts, R. Haight, J. Kagan, A. Starfield, and C. Tobalske. 2008. Where to put things? Spatial land management to sustain biodiversity and economic returns. Biological Conservation 141(6):1505-1524. http://dx.doi. org/10.1016/j.biocon.2008.03.022

Poorter, L., F. Bongers, T. M. Aide, A. M. Almeyda Zambrano, P. Balvanera, J. M. Becknell, V. Boukili, P. H. S. Brancalion, E. N. Broadbent, R. L. Chazdon, D. Craven, J. S. de Almeida-Cortez, G. A. L. Cabral, B. H. J. de Jong, J. S. Denslow, D. H. Dent, S. J. DeWalt, J. M. Dupuy, S. M. Durán, M. M. Espírito-Santo, M. C. Fandino, R. G. César, J. S. Hall, J. L. Hernandez-Stefanoni, C. C. Jakovac, A. B. Junqueira, D. Kennard, S. G. Letcher, J.-C. Licona, M. Lohbeck, E. Marín-Spiotta, M. Martínez-Ramos, P. Massoca, J. A. Meave, R. Mesquita, F. Mora, R. Muñoz, R. Muscarella, Y. R. F. Nunes, S. Ochoa-Gaona, A. A. de Oliveira, E. Orihuela-Belmonte, M. Peña-Claros, E. A. Pérez-García, D. Piotto, J. S. Powers, J. Rodríguez-Velázquez, I. E. Romero-Pérez, J. Ruíz, J. G. Saldarriaga, A. Sanchez-Azofeifa, N. B. Schwartz, M. K. Steininger, N. G. Swenson, M. Toledo, M. Uriarte, M. van Breugel, H. van der Wal, M. D. M. Veloso, H. F. M. Vester, A. Vicentini, I. C. G. Vieira, T. V. Bentos, G. B. Williamson, and D. M. A. Rozendaal. 2016. Biomass resilience of neotropical secondary forests. Nature 530(7589):211-214. http://dx.doi. org/10.1038/nature16512

Portillo-Quintero, C., A. Sanchez-Azofeifa, J. Calvo-Alvarado, M. Quesada, and M. M. do Espirito-Santo. 2015. The role of tropical dry forests for biodiversity, carbon and water conservation in the neotropics: lessons learned and opportunities for its sustainable management. Regional Environmental Change 15(6):1039-1049. http://dx.doi.org/10.1007/s10113-014-0689-6

Quijas, S. 2012. Diversidad vegetal y generación de servicios ecosistémicos a diferentes escalas espaciales. Dissertation. Universidad Nacional Autónoma de México, Morelia, México.

R Development Core Team. 2015. R: a language and environment for statistical computing. R Foundation for Statistical Computing, Vienna, Austria. [online] URL: http://www.R-project.org/

Raudsepp-Hearne, C., G. D. Peterson, and E. M. Bennett. 2010. Ecosystem service bundles for analyzing tradeoffs in diverse landscapes. Proceedings of the National Academy of Sciences 107 (11):5242-5247. http://dx.doi.org/10.1073/pnas.0907284107

Rendón-Carmona, H., A. Martínez-Yríar, P. Balvanera, and D. Pérez-Salicrup. 2009. Selective cutting of woody species in a Mexican tropical dry forest: incompatibility between use and conservation. Forest Ecology and Management 257(2):567-579. http://dx.doi.org/10.1016/j.foreco.2008.09.031
Ribeiro, E. M. S., V. Arroyo-Rodríguez, B. A. Santos, M. Tabarelli, and I. R. Leal. 2015. Chronic anthropogenic disturbance drives the biological impoverishment of the Brazilian Caatinga vegetation. Journal of Applied Ecology 52(3):611-620. http://dx.doi.org/10.1111/1365-2664.12420

Rodríguez, J. P., T. D. Beard, E. M. Bennett, G. S. Cumming, S. J. Cork, J. Agard, A. P. Dobson, and G. D. Peterson. 2006. Tradeoffs across space, time, and ecosystem services. Ecology and Society 11(1):28. [online] URL: http://www.ecologyandsociety. org/vol11/iss1/art28/ http://dx.doi.org/10.5751/es-01667-110128

Rogers, E. M. 2003. Diffusion of innovations. Fifth Edition. Free, New York, New York, USA.

Ruijs, A., A. Wossink, M. Kortelainen, R. Alkemade, and C. J. E. Schulp. 2013. Trade-off analysis of ecosystem services in Eastern Europe. Ecosystem Services 4:82-94. http://dx.doi. org/10.1016/j.ecoser.2013.04.002

Salmerón, O. U. 2015. Valor económico y disyuntivas ambientales en el manejo del bosque tropical seco en Chamela, Jalisco. Thesis. Universidad Nacional Autónoma de México, Morelia, México.

Sánchez-Azofeifa, G. A., and C. Portillo-Quintero. 2011. Extent and drivers of change of neotropical seasonally dry tropical forests. Pages 45-57 in R. Dirzo, H. S. Young, H. A. Mooney, and G. Ceballos, editors. Seasonally dry tropical forests. Ecology and conservation. Island, Washington, D.C., USA. http://dx.doi. org/10.5822/978-1-61091-021-7 3

Sánchez-Azofeifa, G. A., M. Quesada, P. Cuevas-Reyes, A. Castillo, and G. Sánchez-Montoya. 2009. Land cover and conservation in the area of influence of the Chamela-Cuixmala Biosphere Reserve, Mexico. Forest Ecology and Management 258 (6):907-912. http://dx.doi.org/10.1016/j.foreco.2008.10.030

Shadow, R. D. 2002. Tierra, trabajo y ganado en la región Norte de Jalisco: una historia agraria de Villa Guerrero, Jalisco, 1600-1980. El Colegio de Michoacán AC, Zamora, México.

Sircely, J., and S. Naeem. 2012. Relationships of overstory trees and shrubs with forage species portray ecosystem service interactions in smallholder fallows. Agroforestry Systems 87 (2):451-464. http://dx.doi.org/10.1007/s10457-012-9566-9

Skutsch, M., A. Borrego, L. Morales-Barquero, J. PanequeGálvez, M. Salinas-Melgoza, M. I. Ramírez, D. Pérez-Salicrup, D. Benet, S. Monroy, and Y. Gao. 2015. Opportunities, constraints and perceptions of rural communities regarding their potential to contribute to forest landscape transitions under REDD +: case studies from Mexico. International Forestry Review 17(SI):65-84. http://dx.doi.org/10.1505/146554815814669025

Soto, J. C. 2009. Plantas útiles de la cuenca del Balsas. Pages 277-310 in G. Ceballos, L. Martínez, A. García, E. Espinoza, J. Bezaury, and R. Dirzo, editors. Diversidad, amenazas y áreas prioritarias para la conservaciín de las Selvas Secas del Pacíico de México. Fondo de Cultura Económica, México, D.F.

Tallis, H., P. Kareiva, M. Marvier, and A. Chang. 2008. An ecosystem services framework to support both practical conservation and economic development. Proceedings of the National Academy of Sciences 105(28):9457-9464. http://dx.doi. org/10.1073/pnas.0705797105 
Trilleras, J. M., V. J. Jaramillo, E. V. Vega, and P. Balvanera. 2015. Effects of livestock management on the supply of ecosystem services in pastures in a tropical dry region of western Mexico. Agriculture, Ecosystems and Environment 211:133-144. http://dx. doi.org/10.1016/j.agee.2015.06.011 
Appendix 1. Plot level relation between $C$ stocks in aboveground biomass of trees and rarefied tree species richness in tropical dry forests and pasture sites within and adjacent to the ChamelaCuixmala Biosphere Reserve.

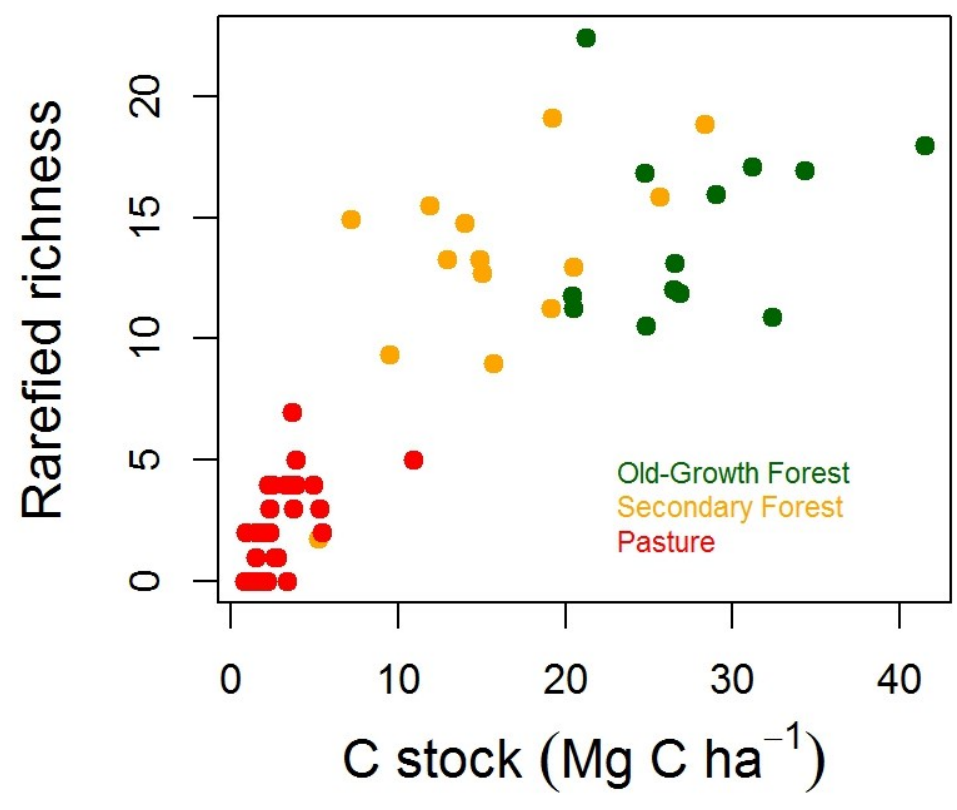

